\title{
Minimal Rates of Oxygen Consumption in Sick and Premature Newborn Infants
}

\author{
J. W. SCOPES and IQBAL AHMED \\ From the Nuffield Neonatal Research Unit, Institute of Child Health, Hammersmith Hospital, London W.12
}

The total energy expenditure of the living organism has been the subject of interest and research since the eighteenth century when Lavoisier made the fundamental observation that energy is produced in the body by the process of oxidation. The quantity of heat produced by a subject can be measured by direct calorimetry, or indirectly by measurement of the gaseous exchange between a subject and his atmosphere and calculation of heat produced.

Use of indirect calorimetry in children was reported as early as 1843 (Andral and Gavarret, 1843; Scharling, 1843), but it was Rubner and Heubner (1898) at the end of the nineteenth century who first devoted detailed attention to very young babies. Since then Benedict and Talbot (1914), Karlberg (1952), and Brück (1961) have reported work to which constant reference is made by workers in this field.

Study of metabolic rate and of temperature control are obviously closely related, and newborn babies, especially if premature, are well known to show thermal instability. The purpose of this study was to obtain more information on metabolic rate in babies in the first hours, days, and weeks of life, and to relate it to size, maturity, age, thermal stability and other aspects of neonatal pathology and physiology. This paper is concerned only with minimal rates of $\mathrm{O}_{2}$ consumption.

An individual's energy metabolism varies considerably and rapidly with such factors as exercise, environmental temperature, and food. In order to compare one individual with another, conditions should be as uniform as possible. In adults the conditions usually described as 'basal' are when the individual is awake, completely quiet physically, and fasting-usually taken early in the morning. These conditions can hardly be described as truly basal (for instance, various workers have found that during a night's sleep energy metabolism is lower still (Wang and Kern, 1928; Bruin, 1931)). Some authors,

Received January 31, 1966. therefore, prefer the term 'standard metabolism' (Bierring, 1931; Du Bois, 1936; Karlberg, 1952).

With a baby, the fasting state is unsatisfactory for examining 'basal' metabolism. He is always digesting one meal or actively anticipating the next. Lee and Iliff (1956) showed in older babies and children that metabolic rate in the awake and fasting state is higher than when the child is in post-prandial sleep. Some workers have chosen the fasting state using a small dose of barbiturate to prevent 'uneasiness' (Baer, 1929; Schadow, 1929; Karlberg, 1952). The 'specific dynamic action' of food in infants is less pronounced than in adults, the maximal increase in energy metabolism being of the order of $4-10 \%$ after an ordinary feed (McCance and Strangeways, 1954; Levine, Wilson, and Gottschall, 1928).

Until about 1940, the importance of environmental temperature and neutral range in babies was not fully appreciated. In 1943 Day, Curtis, and Kelly showed that premature babies more than a week old increased metabolism in the cold, but as recently as 1958 Silverman, Fertig, and Berger were unable to find satisfactory evidence that premature babies less than a week old had a metabolic increase in the cold. The result is that, in much of the early work, it is far from clear whether babies were in a neutral thermal environment when 'basal metabolism' was measured. To avoid assumptions implicit in terms 'basal' or 'metabolic rate' in the paper, we have quoted results in terms of what was actually measured, i.e. observed minimal rate of $\mathrm{O}_{2}$ consumption. (For purposes of comparison $1 \mathrm{ml} . / \mathrm{kg}$. min. $=4.825 \mathrm{cal} . / \mathrm{kg}$. $\mathrm{min} .=0.29 \mathrm{k}$. cal. $/ \mathrm{kg}$. hr. $=6.95 \mathrm{k}$. cal. $/ \mathrm{kg} .24 \mathrm{hr}$.)

\section{Methods}

An apparatus whereby $\mathrm{O}_{2}$ consumption was measured by the closed circuit principle was built in the workshop of the Postgraduate Medical School. In a thermostatically controlled system, air or other oxygen mixtures were circulated at $251 . / \mathrm{min}$. over the baby who took up oxygen, giving off carbon dioxide and water vapour. These were removed by soda lime and a 
condenser, respectively; any diminution in circuit volume was, therefore, due to the oxygen consumed. Oxygen was replaced automatically to maintain the volume and oxygen content of the circulating gases. The oxygen used for replacement was taken from a sensitive recording spirometer which was refilled every minute from an oxygen reservoir. A system resulted in which any environmental temperature and any oxygen concentration of circulating gas could be chosen and these factors held constant, while the minute by minute oxygen consumption was measured and recorded. The baby, who had no mask or facepiece, lay undisturbed and under continual observation. He could be removed in a matter of seconds should there be any concern about his condition. For a more detailed description of the performance and accuracy of the apparatus see Scopes (1965), or Hill and Rahimtulla (1965) whose apparatus was very similar.

Temperatures were measured by thermocouples or thermistors and included colonic temperature (inserted $10 \mathrm{~cm}$.-Karlberg, 1949), skin temperature (usually abdominal wall), wet and dry bulb temperatures of ambient air, water bath temperature, and room temperature. On some occasions, respiration was recorded continuously by an impedance pneumograph (Pallett and Scopes, 1965).

Physical activity was observed continuously and recorded on the chart displaying $\mathrm{O}_{2}$ consumption, using the arbitrary scale shown in Table I. Only Scores 0 or 1 were acceptable in measuring minimal rates of $\mathrm{O}_{2}$ consumption, and periods of such inactivity lasting 10 or more minutes were taken as representative. All measurements of $\mathrm{O}_{2}$ consumption were reduced to STP (dry gas) and expressed as $\mathrm{ml} . / \mathrm{kg}$. $\mathrm{min}$.

TABLE I

Arbitrary Scale Used to Score Activity

\begin{tabular}{|c|c|}
\hline Score & Activity \\
\hline $\begin{array}{l}0 \\
1\end{array}$ & $\begin{array}{l}\text { Asleep, eyes closed, physically quiet } \\
\text { Eyes open but physically quiet, or eyes closed with }\end{array}$ \\
\hline 2 & $\begin{array}{l}\text { Awake with minor irregular and discontinuous } \\
\text { movements }\end{array}$ \\
\hline $\begin{array}{l}3 \\
4\end{array}$ & $\begin{array}{l}\text { More continuous and powerful movements } \\
\text { Mild crying with considerable activity }\end{array}$ \\
\hline
\end{tabular}

The babies examined were always being fed normally (for their clinical state) and were usually examined after food when they were sleeping. No drugs were given. No correction was made for deep body temperature and no particular time of day was preferred. The environmental temperature, i.e. dry bulb air thermometer temperature, was always in the neutral range (proven for the individual baby or assumed for a baby of that particular size and clinical state from ranges previously identified (Scopes and Ahmed, 1966)). The air flow rate past the baby was constant at approximately $1 \mathrm{~m}$./ min., and the vapour pressure was constant, relative humidity being approximately $35 \%$-the exact relative humidity depended on the temperature of the chamber and of the condenser.

Where blood analysis was necessary, blood was taken by heel prick or from an indwelling umbilical catheter. In each case, the catheter had been inserted as part of the treatment for which the child had been admitted. Estimations were made by micro-techniques after the methods of Huggett and Nixon (1957) (for glucose), and Malloy and Evelyn (1937) (for bilirubin). Gestational age was calculated from the first day of the mother's last menstrual period.

In the case of a normal baby, the mother's permission for the examination was always obtained. Where the examination was useful in assessment of clinical condition or of progress, permission was not always obtained, but any mother who wished was invited to be present at this harmless investigation.

\section{Subjects}

Studies were carried out on 115 babies, usually at several different ages, making a total of more than 350 studies. In many of the studies rates of oxygen consumption were measured at various ambient conditions, so that over 1,200 individual assessments were made. The babies were patients in the Neonatal Unit or lying-in wards of the Hammersmith Hospital.

Every baby is different from his fellow so that grouping babies is necessarily artificial and arbitrary. The following groupings were used.

Group I. Babies of more than 36 weeks' gestation but excluding babies of Group II below. Many of the babies in this group were in the Neonatal Unit because of illness (e.g. haemolytic disease of the newborn, birth asphyxia, etc.). Some were somewhat 'small for dates' (e.g. 36:3 weeks weighing $2,300 \mathrm{~g}$. at birth), but did not fulfil the criteria for Group II below. Therefore this group should not be compared precisely with published studies of normal babies.

Group II. Babies of more than 36 weeks' gestation but of a birthweight at least $750 \mathrm{~g}$. below the weight expected for gestation (herein referred to as 'small for dates'). The expected weights for gestation were taken from the figures of the National Birthday trust survey (British Perinatal Mortality Survey, 1963). $750 \mathrm{~g}$. is a convenient arbitrary figure not far removed from two standard deviations, which between 36 and 40 weeks' gestation does not vary greatly.

Group III. Babies of less than 36 weeks' gestation but of birthweight more than 1,500 g. ('larger prematures').

Group IV. Babies of birthweight less than 1,500 $\mathrm{g}$. ('smaller prematures').

\section{Results}

More than 350 measurements of minimal rate of $\mathrm{O}_{2}$ consumption were made. Within the first 6 hours from birth it is a remarkable fact that despite variations in size, gestation, etc., the minimal rate of consumption is about $4.6 \mathrm{ml}$. $/ \mathrm{kg}$. min. Thereafter 
Minimal Rates of Oxygen Consumption in Sick and Premature Newborn Infants

TABLE II

Minimal Rates of $\mathrm{O}_{2}$ Consumption in Group I Babies (mean birthweight 3,322 g.)

\begin{tabular}{c|c|c|c|c}
\hline Age & No. & $\begin{array}{c}\text { Mean } \\
\text { (ml./kg. } \\
\text { min.) }\end{array}$ & SD & SE \\
\hline $0-6 \mathrm{hr}$. & 15 & $4 \cdot 63$ & $0 \cdot 30$ & $0 \cdot 08$ \\
$9-18 \mathrm{hr}$. & 15 & $4 \cdot 60$ & $0 \cdot 46$ & $0 \cdot 12$ \\
$21-30 \mathrm{hr}$. & 19 & $5 \cdot 33$ & $0 \cdot 63$ & $0 \cdot 14$ \\
$33-47 \mathrm{hr}$. & 11 & $6 \cdot 44$ & $1 \cdot 21$ & $0 \cdot 38$ \\
$48-71 \mathrm{hr}$. & 21 & $5 \cdot 95$ & $0 \cdot 98$ & $0 \cdot 21$ \\
$3-<5$ dy. & 25 & $6 \cdot 15$ & $0 \cdot 75$ & $0 \cdot 15$ \\
$5-<6$ dy. & 13 & $6 \cdot 2$ & $0 \cdot 51$ & $0 \cdot 14$ \\
$6-<8$ dy. & 27 & $6 \cdot 25$ & $0 \cdot 61$ & $0 \cdot 12$ \\
$8-10$ dy. & 13 & $6 \cdot 85$ & $0 \cdot 78$ & $0 \cdot 22$ \\
$11-14$ dy. & 11 & $6 \cdot 9$ & $0 \cdot 60$ & $0 \cdot 18$ \\
$15-21$ dy. & 8 & $6 \cdot 9$ & $0 \cdot 57$ & $0 \cdot 20$ \\
\hline
\end{tabular}

TABLE III

Minimal Rates of $\mathrm{O}_{2}$ Consumption in Group II Babies (mean birthweight 2,088 g.)

\begin{tabular}{c|c|c|c|c}
\hline Age & No. & $\begin{array}{c}\text { Mean } \\
\text { (ml./kg. } \\
\text { min.) }\end{array}$ & SD & SE \\
\hline 9-17 hr. & 7 & $4 \cdot 77$ & $0 \cdot 30$ & $0 \cdot 12$ \\
$18-30 \mathrm{hr}$. & 7 & $4 \cdot 95$ & $0 \cdot 72$ & $0 \cdot 10$ \\
$48-92 \mathrm{hr}$. & 4 & $4 \cdot 85$ & $0 \cdot 73$ & $0 \cdot 18$ \\
$4-5$ dy. & 5 & $6 \cdot 26$ & $0 \cdot 17$ & $0 \cdot 07$ \\
$6-<8$ dy. & 8 & $6 \cdot 69$ & $0 \cdot 54$ & $0 \cdot 19$ \\
$8-11$ dy. & 7 & $7 \cdot 51$ & $1 \cdot 06$ & $0 \cdot 40$ \\
$14-28$ dy. & 8 & $8 \cdot 24$ & $0 \cdot 61$ & $0 \cdot 21$ \\
5 wk. & 1 & $8 \cdot 15$ & - & - \\
\hline
\end{tabular}

there is considerable variation within the different clinical groups. Because the clinical circumstances of no two babies were identical, much of the data related to age appear in a haphazard fashion. For instance, it was not possible to take, say, 20 babies of one group and follow them daily (or hourly). Consequently, all the results were plotted against age on a scattergram. This enables one to see general trends and group the results for statistical purposes in a reasonable way, which will show up the more obvious variations.

The findings for the various groups of babies are given in Tables II to $\mathrm{V}$ and combined in the composite Fig. 1. The figure also includes the results of Hill and Rahimtulla (1965) obtained with a similar apparatus on normal newborn babies, a group which, because of the population studied, is deficient in the present series. Normal term babies, they found, have a large and highly significant rise in metabolic rate in the first $\mathbf{2 4}$ hours, and thereafter a much smaller rise in the succeeding days.

In the present series Group I babies ( $>36$ weeks' gestation) had no rise at 13 hours (9-18) age. There was then a rise at 24 hours, continuing to 48 hours, where the mean is similar to those of Hill and Rahimtulla. From 2 days to 7 days the rates were
TABLE IV

Minimal Rates of $\mathrm{O}_{2}$ Consumption in Group III Babies (mean birthweight 1,972 g.)

\begin{tabular}{|c|c|c|c|c|}
\hline Age & No. & $\underset{\text { min.) }}{\text { Mean }}$ & SD & SE \\
\hline $\begin{array}{c}0-6 \mathrm{hr} . \\
6-12 \mathrm{hr} . \\
13-36 \mathrm{hr} . \\
2-<3 \mathrm{dy} . \\
3-<5 \mathrm{dy} . \\
5-<7 \mathrm{dy} . \\
7-<8 \mathrm{dy} . \\
8-<11 \mathrm{dy} . \\
11-<14 \mathrm{dy} . \\
14-<21 \mathrm{dy} . \\
21-<35 \mathrm{dy} . \\
42 \mathrm{dy} .\end{array}$ & $\begin{array}{r}14 \\
7 \\
10 \\
6 \\
17 \\
20 \\
8 \\
9 \\
16 \\
17 \\
20 \\
19\end{array}$ & $\begin{array}{l}4 \cdot 40 \\
4 \cdot 57 \\
4 \cdot 78 \\
5 \cdot 17 \\
5 \cdot 23 \\
5 \cdot 55 \\
6 \cdot 22 \\
6 \cdot 45 \\
6 \cdot 53 \\
6 \cdot 56 \\
7 \cdot 31 \\
7 \cdot 38\end{array}$ & $\begin{array}{l}0.45 \\
0.22 \\
0.25 \\
0.36 \\
0.64 \\
0.36 \\
0.25 \\
0.81 \\
0.87 \\
0.96 \\
1.07 \\
0.89\end{array}$ & $\begin{array}{l}0 \cdot 12 \\
0 \cdot 08 \\
0 \cdot 08 \\
0 \cdot 15 \\
0 \cdot 16 \\
0 \cdot 08 \\
0 \cdot 09 \\
0 \cdot 27 \\
0.22 \\
0 \cdot 23 \\
0 \cdot 24 \\
0.20\end{array}$ \\
\hline
\end{tabular}

TABLE V

Minimal Rates of $\mathrm{O}_{2}$ Consumption in Group IV Babies (mean birthweight 1,276 g.)

\begin{tabular}{|c|c|c|c|c|}
\hline Age & No. & $\underset{\text { min.) }}{\text { Mean }}$ & SD & SE \\
\hline $\begin{array}{l}\text { 0-6 hr. } \\
18-36 \mathrm{hr} . \\
2-8 \mathrm{dy} . \\
10-11 \mathrm{dy} . \\
14-20 \mathrm{dy} . \\
21-28 \mathrm{dy} . \\
35-42 \mathrm{dy} . \\
>42 \mathrm{dy} .\end{array}$ & $\begin{array}{r}5 \\
11 \\
9 \\
4 \\
11 \\
5 \\
8 \\
11\end{array}$ & $\begin{array}{l}4 \cdot 51 \\
3 \cdot 51 \\
4 \cdot 90 \\
5 \cdot 74 \\
6 \cdot 75 \\
6 \cdot 74 \\
7 \cdot 10 \\
6 \cdot 95\end{array}$ & $\begin{array}{l}0.81 \\
0.93 \\
0.22 \\
0.31 \\
1.04 \\
0.48 \\
0.81 \\
1.35\end{array}$ & $\begin{array}{l}0 \cdot 36 \\
0 \cdot 29 \\
0 \cdot 07 \\
0 \cdot 16 \\
0 \cdot 32 \\
0 \cdot 22 \\
0 \cdot 31 \\
0 \cdot 41\end{array}$ \\
\hline
\end{tabular}

consistently lower than those of normal babies and thereafter rose to 'normal' levels. The precise reason for this 'depression' from days $2-7$ is uncer-

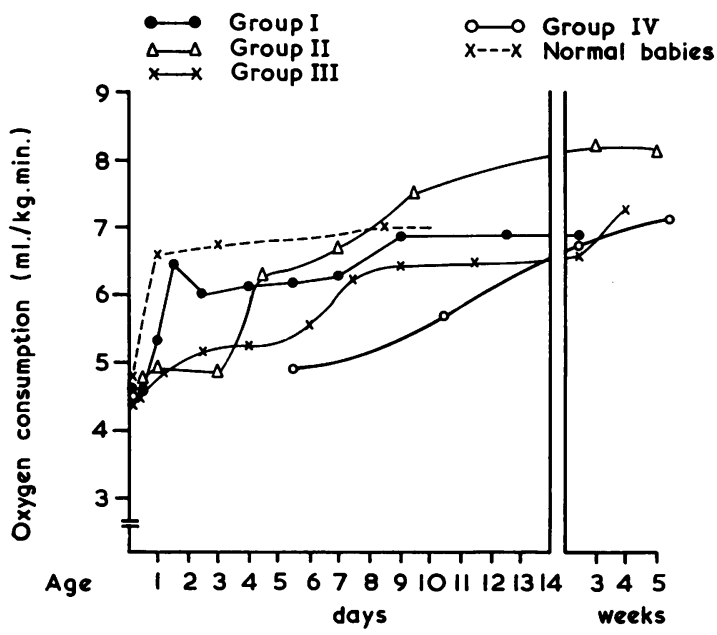

FIG. 1.-Changes of minimal rates of $\mathrm{O}_{2}$ consumption with age. Means are plotted at the midpoint of the age-group. 
tain. Possible explanations would include the following. Babies of Group I were not entirely normal, as explained above, many of them having jaundice, birth asphyxia, etc. Those who recovered completely were discharged from the Neonatal Ward at 48 hours, thus loading the successive days with babies who were ill or small. Many babies included in this group were of relatively short gestation (36-37 weeks) and low birthweight (2,3002,700 g.). Other factors affecting minimal rates of oxygen consumption, which often involved the babies of this group, are discussed below.

The Group II babies ( 36 weeks but 'small for dates') showed no rise in minimal rate for the first 2-3 days of life. Comparing the rates of this group with those of Group I babies in the age 24 hours-75 hours shows a highly significant difference $(p<$ $0 \cdot 001){ }^{\star}$ At 4 days there is a large and significant rise in metabolic rate. Comparing rates $36-72$ hours with rates 4-7 days shows a rise of $1 \cdot 2 \mathrm{ml}$./kg. $\mathrm{min}$. $(\mathbf{p}<0.001){ }^{\star}$ Thereafter these 'small for dates' babies have a high minimal rate compared with 'term' babies, in terms of $\mathrm{ml}$./kg. min. In the agegroup 8 days to 4 weeks it is, on average, higher by $0.9 \mathrm{ml} . / \mathrm{kg}$. min. ( $p<0.001$ ). ${ }^{\star}$ It is interesting, and probably more than coincidental, that during the relative depression of rate of $\mathrm{O}_{2}$ consumption over 1-3 days most of these babies show a tendency to hypoglycaemia (Cornblath, Wybregt, Baens, and Klein, 1964). In any event, these babies are clinically undernourished and deficient in adipose tissue (Aherne and Hull, 1964), and there is good reason to regard them as cases of intrauterine starvation (Gruenwald, 1963). They may be deficient, therefore, in reserves of substrate for oxidation until feeding is well established. The hypermetabolism of days 7-28 may of course be artefactual caused by using weight directly as a correlation factor. However, Sinclair and Silverman (1965) report similar findings, and many authors (Benedict and Talbot, 1914; Levine et al., 1928; Murlin, Conklin, and Marsh, 1925; Janet and Bochet, 1933; Fouet, 1924) have found that underweight children have high metabolic rates (unless overt starvation syndromes supervene). Indeed, there is a clear suggestion that these babies behave as underweight babies who are starved in the first 3 days of life.

The larger premature babies (Group III) show a slow steady rise for the first 6 days of life. The more abrupt rise between day 6 and day 7 is significant $(p<0.001){ }^{\star}$ The low rate compared with 'term' babies over days $2-6$ is also highly significant $(p<0.001){ }^{\star}$ Possible reasons for this

\footnotetext{
$\star$ Students ' $t$ ' test.
}

low rate lie in the clinical state of many of these babies at this age. Common clinical complications are idiopathic respiratory distress syndrome, jaundice, infections, and feeding difficulties. Again it may be more than coincidental that a rise occurs on the 7-8th day when these conditions have usually subsided.

The very small babies (Group IV) have a 'normal' minimal rate of $\mathrm{O}_{2}$ consumption at birth, but thereafter it is consistently low until the age of 2-3 weeks. If metabolic rate were related to surface area, one would expect these babies to have a high rate in terms of ml./kg. min., whereas the reverse is true. The very low rate shown at 24 hours is caused by loading at this age with babies who were very seriously ill, and some of whom died.

\section{Specific Factors Affecting Minimal Rates of $\mathrm{O}_{2}$ Consumption}

Quite apart from factors already considered (environmental temperature, food, activity, and correlation factors of height, weight, surface area, etc.) it is clear from the scatter obtained that other factors and conditions affect the minimal rate of $\mathrm{O}_{2}$ consumption. In the adult there is a considerable volume of work on this subject, but many of the factors do not obviously apply in the newborn period. During the course of the present study a number of observations, which seemed pertinent to this aspect, were made and some of them were examined more closely.

(a) Deep body temperature. A principle (ascribed to van't Hoff, 1896) is that there is a change in the rate of chemical reaction with change in temperature. Empirical determinations for biological systems have shown an increase in reaction velocity by a factor of 2 to 3 for each $10^{\circ} \mathrm{C}$. rise in temperature. This effect is usually called the ' $\mathrm{Q} 10$ effect'. In vitro mammalian tissue shows this effect (Fairley, 1961), so it would not be unreasonable to expect it of the total subject, and indeed the whole principle of surgical operations with hypothermia depends on the effect. (A Q10 effect of 2-3 represents a change of rate of $10-12 \%$ per ${ }^{\circ} \mathrm{C}$.) However, in the intact homeothermic subject, cooling is physiologically countered by a rise in metabolism. None the less, if all observations were made in an environment where there was no known physiological stimulus to heat production, one still might expect to demonstrate a Q10 effect in babies. In fact, several authors (Adamsons, Gandy, and James, 1965; Mestyán, Fekete, Bata, and Járai, 1964; Hill and Rahimtulla, 1965) have failed to demonstrate this effect. 
Babies in a neutral thermal environment would be expected to have no stimulus to heat production from skin receptors. Under these conditions plotting rectal temperature against rate of $\mathrm{O}_{2}$ consumption gives no significant correlation when all babies are taken as a single group. In the babies under 24 hours of age, however, the correlation is significant $(p<0.05)$. For the babies under 6 hours of age the correlation is highly significant. Plotting log $\mathrm{O}_{2}$ consumption against temperature (and even excluding the 4 coldest babies) still gives a significant correlation ( $\mathrm{p}<0.01)$. The calculated best regression lines are $y=0.04379 x-0.8753$ and $x=14 \cdot 23 y+25 \cdot 42\left(y=\log \mathrm{O}_{2}\right.$ consumption, $\mathbf{x}=$ rectal temp.). Expressed in antilog form the slope is equivalent to a $\mathrm{Q} 10$ of $2 \cdot 74$, agreeing well with the expected Q10 for biological systems.

In one particular baby, with a large encephalocele, whose peripheral nerves were apparently intact and who later at necropsy was shown to have abundant brown fat, a Q10 effect was clearly demonstrable. At a colonic temperature of $34 \cdot 3^{\circ} \mathrm{C}$. her rate of $\mathrm{O}_{2}$ consumption was $3.1 \mathrm{ml} . / \mathrm{kg}$. min. When she had been warmed to 35.3 the rate was $3.55 \mathrm{ml} . / \mathrm{kg}$. min. -a significant increase of $14 \%$ for $1^{\circ} \mathrm{C}$. rise. When warmed to $36 \cdot 4^{\circ} \mathrm{C}$. there was a further rise of $13 \%$ (over $3.55 \mathrm{ml} . / \mathrm{kg}$. min.) for $1 \cdot 1^{\circ} \mathrm{C}$. rise in rectal temperature. (These measurements were made in neutral environmental thermal conditions for age, gestation, and size, and on the third day of life when the rise cannot be attributed to advancing age between the first and last measurement.)

The most obvious explanation of why a Q10 effect is difficult to demonstrate is that it is masked by physiological stimulus to deep cold receptors. If this is so, one might expect, and indeed it is true, that under anaesthesia (Fairley, 1961) and where no metabolic response at all occurs (above case and in an anencephalic baby (J. R. Hill, 1965, personal communication)) one can demonstrate a Q10 effect. That it shows clearly in these young babies and disappears after 24 hours suggests that either extreme youth or the effects of birth suppress the action of central cold receptors. It may also be true that in demonstrating a Q10 effect, it is important to examine a 'mixed bag' of premature and other abnormal babies in whom normal homeostatic function may be deranged, because careful work by Adamsons et al. (1965), Mestyán et al. (1964), and Hill and Rahimtulla (1965) on normal babies failed to demonstrate a process which is unequivocally shown in the present data. Indeed, one could say that the most interesting fact about the Q10 effect is that it is difficult to demonstrate, rather than that it is demonstrable. (b) Prematurity. Apart from the first hours after birth, premature babies show a low $\mathrm{O}_{2}$ consumption rate compared with term babies, as shown above. This may well be an artefact arising from the use of body weight as a correlation factor (Sinclair, Scopes, and Silverman, 1966). It appears to be the effect of maturity rather than of size, since 'small for dates' babies-after the 4th day-do not show the same effect. In general, the more immature the child, the lower the rate of $\mathrm{O}_{2}$ consumption (see Fig. 1 and Mestyán et al., 1964) and the closer the rate to that obtaining in the mother (3.65 ml./kg. min.; Döbeln, 1956).

The precise reason why prematurity should be associated with a lower metabolic rate is difficult to define, as the mechanism whereby basal metabolic rate is controlled is not understood (see discussion). The finding is in general agreement with other workers (e.g. Brück, 1961; Mestyán et al., 1964). The relation to post-conceptual age is interesting. While it is generally true that the more immature babies have low metabolic rates, postnatal age also plays a part-babies of 6 weeks old, even if very immature at birth and still small in size, have metabolic rates which are not low (Fig. 1).

(c) Depth of sleep. It is well known that, in rather vague terms, the depth of sleep in babies varies. Goldie and Van Velzer (1965) have described precisely a rhythm that occurs in natural postprandial sleep in babies, and involves two phases that are clearly distinguishable clinically and electroencephalographically. Phase 1 (deep sleep) lasts 14 minutes on average and alternates with Phase 2 (light sleep) which lasts on average 47 minutes.

On at least 20 occasions in the present series, a baby's $\mathrm{O}_{2}$ consumption rate was measured continuously as the 2 phases, distinguished by clinical observations (eye movements, respirations, and body movement) succeeded each other. In most cases, but not all, deep sleep preceded lighter sleep in the observation period. On all occasions the rate of $\mathrm{O}_{2}$ consumption was higher in the light sleep phase. The difference varied from $+7 \%$ to $+28 \%$, the mean being $+16 \%$. For individual babies the rise was not often significant at the $5 \%$ level, but taking all observations and using the method of paired comparisons, the change was highly significant $(p<0.001)$.

In both phases the baby is unequivocally asleep (in so far as the remark has any meaning with babies) and therefore scores 0 on the arbitrary scale adopted (Table I). The small amount of increased muscular movement and more rapid respiration may account for the rise in lighter sleep, but it is also known that blood pressure is higher in this phase (Gupta and 
Scopes and Ahmed

TABLE VI

Effect of Hypoglycaemia on Minimal Rates of $\mathrm{O}_{2}$ Consumption

\begin{tabular}{|c|c|c|c|c|c|c|c|c|c|c|}
\hline $\begin{array}{l}\text { Case } \\
\text { No. }\end{array}$ & $\begin{array}{l}\text { Birthweight } \\
\text { (g.) }\end{array}$ & $\begin{array}{l}\text { Gesta- } \\
\text { tion } \\
\text { (wk.) }\end{array}$ & $\begin{array}{l}\text { Age at } \\
\text { Testing } \\
\text { (hr.) }\end{array}$ & $\left|\begin{array}{c}\text { Blood } \\
\text { Glucose } \\
(\mathbf{m g} . / 100 \mathrm{ml} .)\end{array}\right|$ & $\begin{array}{l}\text { Rectal } \\
\text { Temp. } \\
{ }^{\circ} \mathrm{C}\end{array}$ & $\begin{array}{c}\text { Ambient } \\
\text { Temp. } \\
{ }^{\circ} \mathrm{C}\end{array}$ & $\begin{array}{l}\mathrm{O}_{2} \text { Cons. } \\
(\mathrm{ml} . / \mathrm{kg} . \\
\text { min.) }\end{array}$ & $\begin{array}{c}\text { Normal } \mathrm{O}_{2} \text { Cons. } \\
\text { (ml./kg. min. } \\
\pm \text { S.D.) }\end{array}$ & $\mathbf{P}$ & $-2 \log _{e} p$ \\
\hline $\begin{array}{l}1 \\
2 \\
3 \\
4 \\
4 \\
5\end{array}$ & $\begin{array}{l}1,564 \\
1,520 \\
3,280 \\
3,280 \\
1,910 \\
1,540\end{array}$ & $\begin{array}{l}30 \\
? 34 \\
373 \\
37 \frac{3}{7} \\
37 \frac{1}{7} \\
37\end{array}$ & $\begin{array}{r}5 \\
20 \\
3 \\
30 \\
30 \\
9\end{array}$ & $\begin{array}{l}<10 \\
<10 \\
<10 \\
18 \\
16 \\
<10\end{array}$ & $\begin{array}{l}34 \cdot 6 \\
35 \cdot 7 \\
35 \cdot 6 \\
37 \cdot 1 \\
37 \cdot 3 \\
37 \cdot 4\end{array}$ & $\begin{array}{l}34 \cdot 7 \\
34 \cdot 5 \\
34 \cdot 1 \\
33 \cdot 7 \\
35 \cdot 1 \\
35 \cdot 5\end{array}$ & $\begin{array}{l}4 \cdot 1 \\
4 \cdot 75 \\
4 \cdot 2 \\
3 \cdot 9 \\
4 \cdot 45 \\
4 \cdot 25\end{array}$ & $\begin{array}{l}4 \cdot 4 \pm \cdot 45 \\
4 \cdot 78 \pm \cdot 25 \\
4 \cdot 63 \pm \cdot 30 \\
5 \cdot 33 \pm \cdot 63 \\
4.95 \pm \cdot 72 \\
4 \cdot 77 \pm \cdot 30\end{array}$ & \multirow[t]{2}{*}{$\begin{array}{l}0.24 \\
0.45 \\
0.179 \\
0.06 \\
0.24 \\
0.04\end{array}$} & \multirow[t]{2}{*}{$\begin{array}{l}2 \cdot 86 \\
1 \cdot 6 \\
3 \cdot 44 \\
5 \cdot 62 \\
2 \cdot 86 \\
6 \cdot 42\end{array}$} \\
\hline $\begin{array}{l}4 \\
5\end{array}$ & 1,540 & 37 & 15 & 85 & $37 \cdot 1$ & $35 \cdot 6$ & $4 \cdot 8$ & $4 \cdot 77 \pm \cdot 30$ & & \\
\hline 6 & 1,630 & 36 & 20 & 15 & $36 \cdot 6$ & $35 \cdot 2$ & $4 \cdot 2$ & $4 \cdot 95 \pm \cdot 72$ & $0 \cdot 17$ & $3 \cdot 54$ \\
\hline
\end{tabular}

$-2 \underset{1}{\sum} \log _{\mathrm{e}} \mathrm{p}=\chi^{2}=26 \cdot 34 ; 2 \mathrm{k}=$ d.f. $=14 ; 0.01<\mathrm{p}<0.05$.

Note: The second measurement in Case 5 was made when the child was no longer hypoglycaemic. It is inserted for comparison (see also text).

Scopes, 1955) and it seems likely that other systems are slightly 'aroused'. It is clear that for strict comparisons of metabolic rate, it is insufficient merely to say that the baby was asleep. The phase of sleep should be defined.

(d) Hypoglycaemia. Normal babies have very low blood glucose levels compared with adults, and it is difficult to define hypoglycaemia in the newborn period. Many authors (e.g. Cornblath et al., 1964) take an arbitrary level of less than $20 \mathrm{mg} . / 100 \mathrm{ml}$. as representing hypoglycaemia. However, many babies have levels lower than this without any apparent ill effect. Most 'small for dates' babies have low blood glucose levels over a period when their $\mathrm{O}_{2}$ consumption rates are observed to be low. In order to assess the metabolic rate of babies with undoubted hypoglycaemia, criteria of either a blood glucose level of less than $10 \mathrm{mg}$. $/ 100 \mathrm{ml}$., or a blood glucose level of less than $20 \mathrm{mg}$. $/ 100 \mathrm{ml}$. associated with clinical symptoms relieved by intravenous glucose, were taken as constituting neonatal hypoglycaemia. Such babies are comparatively rare, and even when they are seen, their pressing clinical need for treatment often prevents an estimation of metabolic rate at a time when they are hypoglycaemic. In the present study only 6 babies fulfilling these stringent criteria were examined. Their particulars are set out in Table VI. Case 2 was an exceptional baby in that despite the very low level of blood glucose, he was well and lively and had a normal metabolic response to a cool environment. Apart from this case all the other babies of this group had very low rates of $\mathrm{O}_{2}$ consumption for their age and gestation (see column 8 ). The numbers are small, but by the statistical method of Fisher (1950) the significance is between 0.05 and 0.01 (see Table VI).

Perhaps the most interesting single example is that of Case 5. She was a 'small for dates' baby who at the age of 9 hours was lethargic with extremely shallow irregular breathing. Her blood glucose was found to be less than $10 \mathrm{mg} . / 100 \mathrm{ml}$. at a time when her $\mathrm{O}_{2}$ consumption was only $4 \cdot 25 \mathrm{ml} . / \mathrm{kg}$. min. There was no significant metabolic response and no arousal when she was exposed to an environment of $27^{\circ} \mathrm{C}$. She was given an intravenous glucose load $(0.75$ g. $)$. At 15 hours the blood glucose level was $85 \mathrm{mg} . / 100 \mathrm{ml}$., the child looked well and breathing was normal. The minimal rate of $\mathrm{O}_{2}$ consumption was now normal $(4 \cdot 8 \mathrm{ml} . / \mathrm{kg}$. min.), and on cooling the ambient temperature to $28 \cdot 5^{\circ} \mathrm{C}$. there was a normal clinical response and a $30 \%$ rise in rate of $\mathrm{O}_{2}$ consumption. J. R. Chalnacky (1965, personal communication) has studied a case with the same features, relieved after administration of glucose.

Although the numbers are very small, there is clearly an association between hypoglycaemia and low rates of $\mathrm{O}_{2}$ consumption. Whether they are directly related is uncertain, and both findings may be due to a third factor, such as intrauterine malnutrition. However, one baby of a diabetic mother, who became hypoglycaemic, behaved in a way typical of the group and other babies of diabetic mothers had normal or high rates of consumption. The findings with Case 5 suggest that treating the hypoglycaemia with intravenous glucose 'cured' the low metabolic rate.

(e) Hyperbilirubinaemia. Jaundice is a common finding in newborn babies, especially in premature babies. Mild or moderate jaundice was consequently frequently present in babies of groups III and IV. When clinically mild, serum bilirubin levels were not estimated, and there was no immediately obvious effect on rate of $\mathrm{O}_{2}$ consumption or metabolic response to cold. Indeed, one baby 
TABLE VII

Minimal Rates of $\mathrm{O}_{2}$ Consumption in Seriously Jaundiced Babies

\begin{tabular}{|c|c|c|c|c|c|c|c|c|}
\hline $\begin{array}{l}\text { Case } \\
\text { No. }\end{array}$ & $\begin{array}{c}\text { Birthweight } \\
\text { (g.) }\end{array}$ & $\begin{array}{c}\text { Gestation } \\
\text { (wk.) }\end{array}$ & $\underset{\text { Bilirubin }}{\text { Maximum }}$ & $\begin{array}{l}\text { Exchange } \\
\text { Transfusion }\end{array}$ & $\begin{array}{c}\mathrm{O}_{2} \text { Consumption } \\
\text { (ml./kg. min.) } \\
\text { At Height of } \\
\text { Jaundice }\end{array}$ & $\begin{array}{c}\mathrm{O}_{2} \text { Consumption } \\
\text { (ml./kg. min.) } \\
\text { After Recovery }\end{array}$ & $\begin{array}{c}\text { Absolute } \\
\text { Rate Low } \\
\text { While } \\
\text { Jaundiced }\end{array}$ & $\begin{array}{c}\text { Rise After } \\
\text { Recovery } \\
\text { Dispropor- } \\
\text { tionately } \\
\text { Large }\end{array}$ \\
\hline $\begin{array}{c}1 \\
2 \\
3 \\
4 \\
4 \\
5 \\
6 \\
7 \\
8 \\
9 \\
10 \\
11 \\
12 \\
13 \\
14\end{array}$ & $\begin{array}{l}2,080 \\
2,100 \\
2,090 \\
2,430 \\
3,400 \\
3,800 \\
2,520 \\
3,160 \\
2,460 \\
2,578 \\
1,840 \\
2,360 \\
3,000 \\
3,750\end{array}$ & $\begin{array}{l}33 \\
? 36 \\
34 \\
35 \\
40 \frac{2}{7} \\
40 \frac{1}{7} \\
37 \\
38 \\
33 \frac{3}{7} \\
32 \\
33 \frac{1}{7} \\
37 \\
? 36+ \\
37\end{array}$ & $\begin{array}{l}18 \\
23 \\
25 \\
18 \\
19 \\
24 \\
18 \\
20 \\
18 \\
22 \\
19 \\
21 \\
31 \\
29\end{array}$ & $\begin{array}{l}\times 1 \\
\times 4 \\
= \\
\times 1 \\
\times 1 \\
= \\
- \\
\times 3 \\
-1 \\
\times 1\end{array}$ & $\begin{array}{l}4 \cdot 65 \text { (3 dy.) } \\
4 \cdot 85 \text { (3 dy.) } \\
5 \cdot 8 \text { (6 dy.) } \\
5 \cdot 0 \text { (6 dy.) } \\
6 \cdot 25 \text { (4 dy.) } \\
6 \cdot 1 \text { (4 dy.) } \\
4 \cdot 0 \text { (2 dy.) } \\
5 \cdot 4(7 \text { dy.) } \\
6 \cdot 1(5 \text { dy.) } \\
5 \cdot 35 \text { (2 dy.) } \\
5 \cdot 3 \text { (5 dy.) } \\
5 \cdot 9 \text { (5 dy.) } \\
6 \cdot 1 \text { (5 dy.) } \\
6 \cdot 3 \text { (10 dy.) }\end{array}$ & $\begin{array}{l}6 \cdot 0 \text { (10 dy.) } \\
6 \cdot 7 \text { (9 dy.) } \\
7 \cdot 8 \text { (13 dy.) } \\
6 \cdot 1 \text { (14 dy.) } \\
7 \cdot 55 \text { (11 dy.) } \\
6 \cdot 75 \text { (6 dy.) } \\
6 \cdot 0515 \text { dy.) } \\
= \\
6 \cdot 0(4 \text { dy.) } \\
6 \cdot 1 \text { ( } 8 \text { dy.) } \\
5 \cdot 6(6 \text { dy.) } \\
7 \cdot 3(16 \text { dy.) }\end{array}$ & $\begin{array}{l}\text { Yes } \\
\text { Yes } \\
\text { No } \\
\text { Yes } \\
\text { No } \\
\text { Yes } \\
\text { Yes } \\
\text { Yes } \\
\text { No } \\
\text { No } \\
\text { Yes } \\
\text { Yes } \\
\text { No } \\
\text { Yes }\end{array}$ & $\begin{array}{l}\text { Yes } \\
\text { Yes } \\
\text { Yes } \\
\text { Yes } \\
\text { Yes } \\
\text { Yes } \\
\text { Yes } \\
\text { - } \\
\text { Yes } \\
\text { No } \\
\text { No } \\
\overline{\text { Yes }}\end{array}$ \\
\hline
\end{tabular}

Rise after recovery $(\Delta \mathrm{V}-\Delta \mathrm{V}$ expected for age change) is significant for group. $\mathrm{t}=3 \cdot 387 . \quad \mathrm{df}=9 . \quad \mathrm{p}<0 \cdot 01$.

admitted from another hospital with severe jaundice (bilirubin level $29 \mathrm{mg} . / 100 \mathrm{ml}$.) had a rate of $\mathrm{O}_{2}$ consumption only just below the mean for her age and gestation. This child was, however, despite her high bilirubin level, completely well clinically and was active. However, it was noted that many babies with high bilirubin levels, associated with mild lethargy and slowness with feeds, had low rates of oxygen consumption. The evidence for this statement is far from conclusive, and is hard to test statistically.

Fourteen babies with moderate to severe jaundice (bilirubin level greater than $18 \mathrm{mg} . / 100 \mathrm{ml}$.) were examined repeatedly. There was no significant correlation between bilirubin level and $\mathrm{O}_{2}$ consumption on direct comparison, and with 2 babies in whom there was no clinical lethargy, rates of $\mathrm{O}_{2}$ consumption were normal. In the other 12 there was evidence of a depressed $\mathrm{O}_{2}$ consumption. The absolute rate was low compared with other babies of the same age and gestation, and/or the rate of consumption was low compared with that baby's own rate of consumption after the jaundice had subsided. The details of the 15 babies are set out in Table VII and examples of the effects of severe jaundice are shown in Fig. 2. In Cases 1 and 2, the rate of consumption is low both absolutely and compared with the rate of consumption later in life. In Case 3 the rate of consumption, though not low in absolute terms, is low compared with the rate of consumption later in life. It is noteworthy that exchange transfusion, which reduced the bilirubin level, never immediately increased rate of consumption which only recovered as the jaundice subsided naturally.

Severe jaundice therefore appears to be associated with a depressed rate of $\mathrm{O}_{2}$ consumption. The lack of direct correlation and the exceptions made a direct causal relationship unlikely. There are two more likely explanations of the association. (1) Both the hyperbilirubinaemia and the depressed rate of consumption are caused by another factor. (2) Hyperbilirubinaemia, well known for its variability of clinical effect, only affects $\mathrm{O}_{2}$ consumption when it has affected the central nervous system and caused lethargy. Either of these hypotheses, which are not mutually exclusive, would be consistent with the present evidence.

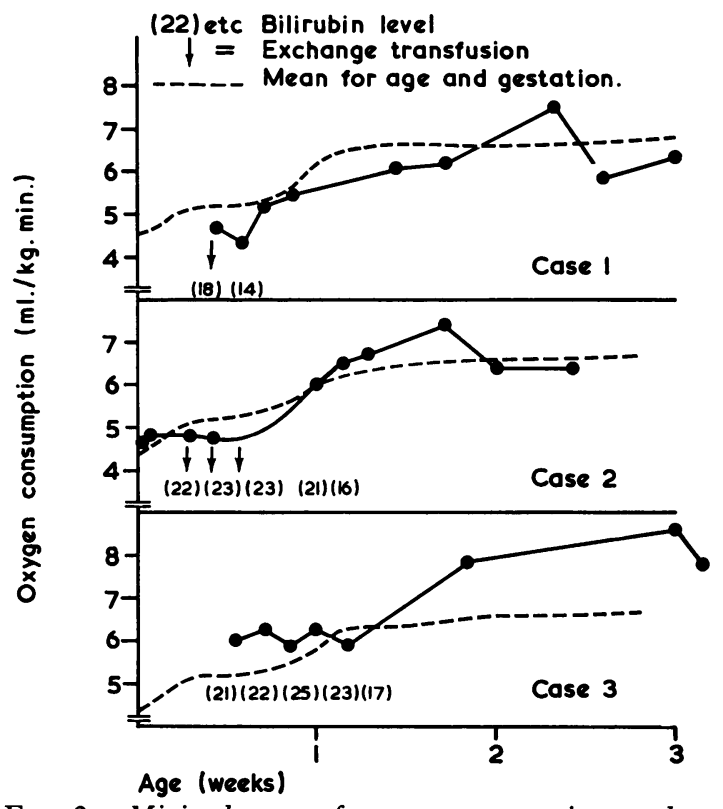

FIG. 2.-Minimal rates of oxygen consumption in three seriously jaundiced babies. Case numbers refer to Table VII. 
(f) Other factors. One proved cretin, aged 7 weeks, was examined. Her metabolic rate was only $4.75 \mathrm{ml} . / \mathrm{kg}$. min. and her critical temperature was very high $\left(34^{\circ} \mathrm{C}\right.$.) at an age where the normal rate would be about $7-8 \mathrm{ml} . / \mathrm{kg}$. min. and the normal critical temperature about $29^{\circ}-30^{\circ}$ C. Over 20 babies with idiopathic respiratory distress syndrome of the newborn had rates of $\mathrm{O}_{2}$ consumption that were not significantly different from the normal for their size and gestation, provided they were adequately oxygenated. Compared with the normal term baby, of course, they were significantly low. One baby's rate of $\mathrm{O}_{2}$ consumption through a long period of periodic breathing (common in premature babies) was compared with her rate when she converted to regular rhythm. There was no difference.

\section{Discussion}

Until the work of Day et al. (1943) it was not generally realized that a baby has a metabolic increase in response to cold at surprisingly warm ambient temperatures. Consequently earlier work is not directly comparable with this. Even in more recent work (e.g. Karlberg, 1952; Cross, Tizard, and Trythall, 1958) the importance of ambient temperature is not emphasized. It might be expected that, in early work, rates recorded at birth would be high because the child was not in a basal state. For instance, Benedict and Talbot (1921) found the basal rate (re-expressed as $\mathrm{ml} . / \mathrm{kg}$. min.) to be $5 \cdot 35 \pm 0 \cdot 11$ S.E., and Karlberg's individual levels are high. More recent work, however, agrees very closely with the present findings (Adamsons et al. (1965) - 4.6 \pm 0.08 S.E. ml./kg. min.; Brück (1961) $-4 \cdot 77 \pm 0 \cdot 11$ S.E.; Hill and Rahimtulla (1965) $-4.76 \pm 0.09$ S.E.). In term babies, there is general agreement that metabolic rate rises in the next 2 days though the magnitude of the rise reported varies from author to author (Brück, 1961, 10.5\%, Benedict and Talbot, 1921, 13\%, Hill and Rahimtulla, 1965, 39\%). This may be related to the fact that Brück's figures for $\mathrm{O}_{2}$ consumption in days 2-9 are low compared with the present series or with the figures of Hill and Rahimtulla. In the case of premature babiesusually defined as those with a birthweight of less than 2,500 g.-most authors have found little or no rise in the first few days (Brück, 1961; Schadow, 1929; Talbot, Sisson, Moriarty, and Dalrymple, 1923; Mestyán et al., 1964). Ignoring the slight fluctuations in the first few days, Brück found the mean consumption for premature babies to be 1.45 $\pm 0.017 \mathrm{k}$. cal. $/ \mathrm{kg}$. hr. $(=4.35 \mathrm{ml} . / \mathrm{kg}$. min. $)$, figures that agree with the individual examples of Schadow. Mestyán et al. further divided prema- ture babies into those of birthweight $1,000-1,500 \mathrm{~g}$. and 1,501-2,000 g. They found the rate of consumption to be significantly lower in the smaller babies. Their absolute figures for the smaller group accord with Brück's, but those for the larger prematures were higher. They agreed that there was a steady rise over the first weeks of life, and as in the present series they found a rise at 7 days, though they did not comment upon it. Figures from Adams, Fujiwara, Spears, and Hodgman (1964a, b), Přibylová and Znamenáček (1964) among recent papers are not satisfactory for comparison, either because the thermal conditions were inadequately controlled, or because the figures were too few and too variable. Silverman and Agate's (1964) individual figures agree in general with the present series.

There is general agreement in the published reports that very small babies have a low minimal rate of oxygen consumption in terms of $\mathrm{ml} . / \mathrm{kg}$. min. This rises with increasing age and size to reach a standard level of approximately $7 \mathrm{ml} / \mathrm{kg}$. min. (Benedict and Talbot, 1921; Karlberg, 1952), which applies for the first year of life. In adults the rate is again low in terms of $\mathrm{ml} . / \mathrm{kg}$. min. Since the rate related to weight is low in both very small premature babies and in human adults, it is clear that no single exponent of weight can be used throughout life. In the present series (weight range $905-4,900 \mathrm{~g}$.) the best exponent was $1 \cdot 17$ (Fig. 3). In Karlberg's series $(2 \cdot 8 \mathrm{~kg}$. $-10 \mathrm{~kg}$.) the best exponent was $0 \cdot 918$. In the adult the best exponent is in the order of 0.75 (Kleiber, 1947) to 0.67 (Rubner and Heubner, 1905). Since it is clear that factors other than weight and surface area materially affect minimal metabolic rate, it is futile to press the exponential treatment of data too far. The empirical findings of Kleiber suggest that there is some optimal relation between metabolic rate and mass, but there is no

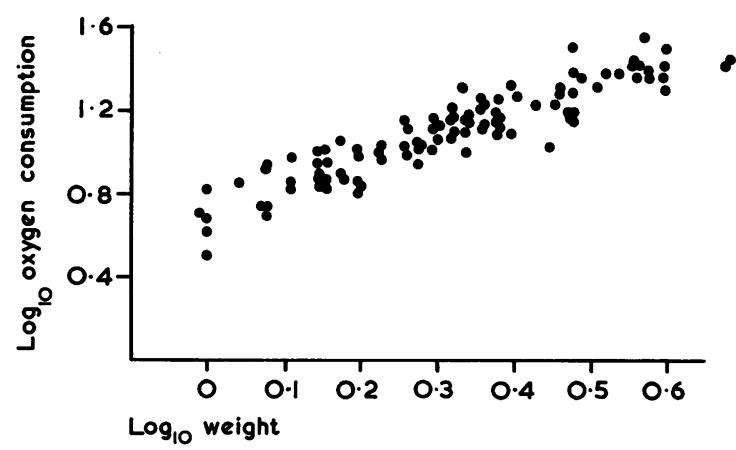

FIG. 3.- $\log _{10}$ oxygen consumption in ml./min. (y) plotted against $\log _{10}$ weight (x) in 100 consecutive babies. The regression line for $\mathrm{y}$ upon $\mathrm{x}$ is $\mathrm{y}=1 \cdot 17 \mathrm{x} \times 0.724 . \quad 99 \%$ confidence limits for slope are 1:01-1-25. 
a priori reason for expecting a newborn, especially a premature, baby in his peculiar environment and state to behave comparably. Sinclair and Silverman (1965) have put forward evidence to suggest that many of the apparent discrepancies in minimal rates of $\mathrm{O}_{2}$ consumption would disappear if a correlation factor of 'active cell mass' were used. For instance, if the metabolic rate of a premature baby (which is low in terms of $\mathrm{ml} . / \mathrm{kg}$. min.) is expressed in terms of cell mass + fat (i.e. total weight minus ECF minus bone mineral) the rate is no longer low. Even this correlation factor however is inadequate to explain the abrupt rise in metabolic rate in 'small for dates' babies on the 4th day of life.

The factors that govern metabolic rate at a cellular level and that, when summated, add up to the metabolic rate of the individual, are far from clear. For instance, the rise in metabolic rate which occurs in the baby in the first few days of extrauterine life (and at a time when weight is not increasing) is common to a number of species, e.g. lambs (Dawes and Mott, 1959), pig (Mount, 1959), monkey (Dawes, Jacobson, Mott, and Shelley, 1960), kitten (Hill, 1959), and puppy (Gelineo, 1954). In some species it is a two- or threefold increase, e.g. lamb and puppy. Dawes (1961) has put forward some possible explanations for this rise. In utero a foetus is thought to have a metabolic rate (per unit weight) similar to that of his mother (Hill, 1961; Romney, Reid, Metcalfe, and Burwell, 1955). The metabolic rate of young women is about $3.65 \mathrm{ml}$./ kg. min. (Döbeln, 1956). The baby's rate when aged 1 week is of the order of $7 \mathrm{ml} . / \mathrm{kg}$. $\mathrm{min}$. The increase after birth is clearly a switch over from a rate appropriate when a baby is a mere part of a much larger mass, to a rate appropriate to a small mass with a separate existence. In this connexion it is interesting that one can extrapolate the rates of $\mathrm{O}_{2}$ consumption shown in Fig. 1 to cross the ordinate at the figure of $3.65 \mathrm{ml} . / \mathrm{kg}$. min. (Fig. 4).

The high metabolic rate of 'small for dates' or fat-deficient babies is similar to the well-known hypermetabolism of experimental animals on a fatdeficient diet (Morris, Panos, Finerty, Wall, and Klein, 1957). This cannot be related to starvation, excessive activity, or hyperthyroidism in the animals. The 'small for dates' baby shows no biochemical evidence of hyperthyroidism (Sinclair and Silverman, 1965; Scopes, 1965) at a time when the clinical picture (irritability, increased pulse rate, and appetite) might suggest it. Thus, there are similarities between these children who are recovering from a fat deficient condition and the fat deficient rat. There is much to suggest that control of metabolic rate in the newborn is mediated by

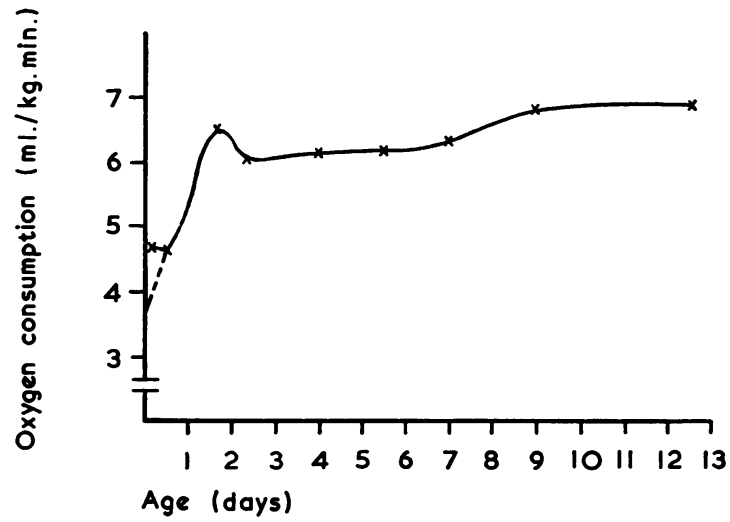

Fig. 4.-Minimal rates of oxygen consumption in Group I babies. The extrapolation back to age 0 is provocative rather than scientific (see text).

catechol amines especially noradrenaline (Moore and Underwood, 1960). The importance of an intact central nervous system and the effect of varying degrees of wakefulness support this suggestion.

\section{Summary}

Minimal rates of $\mathrm{O}_{2}$ consumption were measured in $\mathbf{1 1 5}$ premature and term babies, usually at several different ages, making a total of over 350 measurements. The changes in minimal rates of $\mathrm{O}_{2}$ consumption with age, length of gestation, size, and clinical condition are reported, and some of the factors affecting these rates examined in more detail. All babies have a minimal rate of $\mathrm{O}_{2}$ consumption of about $4.6 \mathrm{ml} / \mathrm{kg}$. min. in the first hours of life. Thereafter, there is a rise in rate, but the magnitude and timing of the rise vary. In babies of more than 36 weeks' gestation the rise occurs within 24 hours. In 'small for dates' babies the rise occurs at the 3rd to 4th day, after which many such babies have high rates of $\mathrm{O}_{2}$ consumption. In premature babies the rise occurs more gradually over a period of days or weeks. Body temperature, depth of sleep, hypoglycaemia, hyperbilirubinaemia, and hypothyroidism all affect minimal rates of $\mathrm{O}_{2}$ consumption.

We are grateful to Professor J. P. M. Tizard, Dr. J. A. Davis, and the resident medical and nursing staff for help, advice, and encouragement. We are also grateful to the Nuffield Foundation, and Heinz Ltd. for fellowships, and to the trustees of the Sir William Coxen Trust Fund for provision of equipment.

REFERENCES

Adams, F. H., Fujiwara, T., Spears, R., and Hodgman, J. (1964a). Gaseous metabolism in premature infants at $32^{\circ}-34^{\circ} \mathrm{C}$. ambient temperature. Pediatrics, 33, 75.

$\longrightarrow,-$, and $-(1964 \mathrm{~b})$. Temperature regulation in premature infants. ibid., 33, 487. 
Adamsons, K., Jr., Gandy, G. M., and James, L. S. (1965). The influence of thermal factors upon oxygen consumption of the newborn human infant. F. Pediat., 66, 495.

Aherne, W., and Hull, D. (1964). The site of heat production in the newborn infant. Proc. roy. Soc. Med., 57, 1172.

Andral, G., and Gavarret, J. (1843). Recherches sur la quantité d'acide carbonique exhalé par le poumon dans l'espèce humaine. Ann. Chim. Phys., ser. 3, 8, 129. (Cited by Benedict and Talbot, 1921.)

Baer, H. (1929). Zur Tecknik der Ruhe-Nüchtern- Umsatz: Bestimmung beim Säughling. Z. Kinderheilk., 47, 226.

Benedict, F. G., and Talbot, F. B. (1914). The Gaseous Metabolism of Infants with Special Reference to Its Relation to Pulse Rate and Muscular Activity. (Carnegie Inst. Publication 201.) Carnegie Inst., Washington.

- and - (1921). Metabolism and Growth from Birth to Puterty. (Carnegie Inst. Publication 302.) Carnegie Inst., Washington

Bierring, E. (1931). The Standard Metabolism of Boys. Levin and Munksgaard, Copenhagen.

British Perinatal Mortality Survey (1963). Perinatal Mortality: The First Report of the 1958 British Perinatal Survey, by N. R. Butler and D. G. Bonham. Livingstone, Edinburgh and London.

Brück, K. (1961). Temperature regulation in the newborn infant. Biol. Neonat. (Basel), 3, 65.

Bruin, M. de (1931). Untersuchungen über den Gastoffweschal gesunder Kinder. $\mathfrak{F b}$. Kinderheilk, 132, 257.

Cornblath, M., Wybregt, S. H., Baens, G. S., and Klein, R. I. (1964). Symptomatic neonatal hypoglycemia. Pediatrics, 33, 388.

Cross, K. W., Tizard, J. P. M., and Trythall, D. A. H. (1958). The gaseous metabolism of the new-born infant breathing $15 \%$ oxygen. Acta paediat. (Uppsala), 47, 217.

Dawes, G. S. (1961). O consumption and hypoxia in the newborn animal. In Ciba Foundation Symposium on Somatic Stability in the Newly Born, ed. G. E. W. Wolstenholme and M. O'Connor. p. 170. Churchill, London.

—, Jacobson, H. N., Mott, J. C., and Shelley, H. J. (1960). Some observations on foetal and new-born rhesus monkeys. $\mathcal{f}$. Physiol. (Lond.), 152, 271.

- and Mott, J. C. (1959). The increase in oxygen consumption of the lamb after birth. ibid., 146, 295.

Day, R. L., Curtis, J., and Kelly, M. (1943). Respiratory metabolism in infancy and in childhood. XXVII. Regulation of body temperature of premature infants. Amer. F. Dis. Child., 65, 376.

Döbeln, W. von (1956). Human standard, and maximal metabolic rate in relation to fat free body mass. Acta physiol. scand., 37, Suppl. 126, 41.

Du Bois, E. F. (1936). Basal Metabolism in Health and Disease, 3rd ed. Lea \& Febiger, Philadelphia.

Fairley, H. B. (1961). Metabolism in hypothermia. Brit. med. Bull., 17, 52.

Fisher, R. A. (1950). Statistical Methods for Research Workers, 11th ed., p. 100 . Oliver and Boyd, Edinburgh.

Fouet, A. (1924). La Metabolisme Basal du Nourrison. These, Paris. (Cited by Karlberg, 1952.)

Gelineo, S. (1954). Le développement otogénique de la thermorégulation chey le chien. C. R. Soc. Biol. (Paris), 148, 1483.

Goldie, L. G., and Van Velzer, C. (1965). The phases of sleep in the newborn baby. Brain, 88, 1043.

Gruenwald, P. (1963). Chronic fetal distress and placental insufficiency. Biol. Neonat. (Basel), 5, 215.

Gupta, J. M., and Scopes, J. W. (1965). Observations on blood pressure in newborn babies. Arch. Dis. Childh., 40, 637.

Hill, J. R. (1959). The oxygen consumption of new-born and adult mammals. f. Physiol. (Lond.), 149, 346.

(1961). The physics and physiology of the development of homeothermy. In Ciba Foundation Symposium on Somatic Stability in the Newly Born, ed. G. E. W. Wolstenholme and M. O'Connor, p. 156. Churchill, London.

and Rahimtulla, K. A. (1965). Heat balance and the metabolic rate of new-born babies. f. Physiol. (Lond.), 180, 239.

van't Hoff, J. H. (1896). Studies in Chemical Dynamics. F. Muller, Amsterdam.

Huggett, A. St. G., and Nixon, D. A. (1957). Use of glucose oxidase, peroxidase, and O-Dianisidine in determination of blood and urinary glucose. Lancet, $2,368$.
Janet, H., and Bochet, M. (1933). Sur le metabolism basal du nourisson. Bull. Soc. Pédiat. Paris, 31, 359.

Karlberg, P. (1949). The significance of depth of insertion of the thermometer for recording rectal temperatures. Acta paediat. (Uppsala), 38, 359.

- (1952). Determination of standard energy metabolism (basal metabolism) in normal infants. ibid., 41, Suppl. 89.

Kleiber, M. (1947). Body size and metabolic rate. Physiol. Rev., 27, 511 .

Lee, V. A., and Iliff, A. (1956). The energy metabolism of infants and young children during postprandial sleep. Pediatrics, 18, 739.

Levine, S. Z., Wilson, J. R., and Gottschall, G. (1928). The respiratory metabolism in infancy and in childhood. $X$. The respiratory exchange in marasmus: specific dynamic action of food in normal and in marasmic infants. Amer. F. Dis. Child., 36, 740.

McCance, R. A., and Strangeways, W. M. B. (1954). Protein katabolism and oxygen consumption during starvation in infants, young adults and old men. Brit. F. Nutr., 8, 21.

Malloy, H. T., and Evelyn, K. A. (1937). The determination of bilirubin with the photoelectric colorimeter. F. biol. Chem., 119, 481.

Mestyán, J., Fekete, M., Bata, G., and Járai, I. (1964). The basal metabolic rate of premature infants. Biol. Neonat.(Basel), 7, 11.

Moore, R. E., and Underwood, M. C. (1960). Noradrenaline as a possible regulator of heat production in the new-born kitten. f. Physiol. (Lond.), 150, 13P.

Morris, D. M., Panos, T. C., Finerty, J. C., Wall, R. L., and Klein, G. F. (1957). Relation of thyroid activity to increased metabolism induced by fat deficiency. $\mathcal{F}$. Nutr., 62, 119.

Mount, L. E. (1959). The metabolic rate of the new-born pig in relation to environmental temperature and to age. $\mathcal{F}$. Physiol. (Lond.), 147, 333.

Murlin, J. R., Conklin, R. E., and Marsh, M. E. (1925). Energy metabolism of normal new-born babies, with special reference to the influence of food and of crying. Amer. F. Dis. Child., 29, 1.

Pallett, J. E., and Scopes, J. W. (1965). Recording respiration in newborn babies by measuring impedance of the chest. Mid. Electron. Biol. Engng., 3, 161.

Pruibylová, H., and Znamenáček, K. (1964). Some aspects of thermoregulatory reactions in newborn infants during the first hours of life. Biol. Neonat. (Basel), 6, 324.

Romney, S. L., Reid, D. E., Metcalfe, J., and Burwell, C. S. (1955) Oxygen utilization by human fetus in utero. Amer. F. Obstet. Gynec., 70, 791.

Rubner, M., and Heubner, O. (1898). Die natürliche Ernährung eines Säuglings. Z. Biol., 36, 1.

- and - (1905). Zur Kenntniss der natürlichen Ernährung des Säughlings. Z. exp. Path. Ther., 1, 1.

Schadow, H. (1929). Grundumsatz und spezifisch-dynamische Wirking bei gesunden Säuglingen. F. Kinderheilk., 126, 50.

Scharling, E. A. (1843). fustus Liebigs Ann. Chem., 45, 214. (Cited by Benedict and Talbot, 1921.)

Scopes, J. W. (1965). Studies in $\mathrm{O}_{2}$ consumption in newborn babies. Ph.D. thesis, London.

- and Ahmed, I. (1966). Range of critical temperatures in sick and premature newborn babies. Arch. Dis. Childh., 41, 417.

Silverman, W. A., and Agate, F. J., Jr. (1964). Variation in cold resistance among small newborn infants. Biol. Neonat. (Basel), $6,113$.

- Fertig, J. W., and Berger, A. P. (1958). The influence of the thermal environment upon the survival of newly born premature infants. Pediatrics, 22, 876.

Sinclair, J. C., Scopes, J. W., and Silverman, W. A. (1966). Metabolic reference standards for the neonate. Communication to American Pediatric Society, p. 14 of official program. To be published.

and Silverman, W. A. (1965). Intrauterine growth in active tissue mass of the human fetus. F. Pediat., 67, 925.

Talbot, F. B., Sisson, W. R., Moriarty, M. E., and Dalrymple, A. J. (1923). The basal metabolism of prematurity. III. Metabolism findings in 21 premature infants. Amer. F. Dis. Child., 26, 29.

Wang, C. C., and Kern, R. (1928). The influence of sleep on basal metabolism of children. ibid, $\mathbf{3 6}, 83$. 